\title{
Kepuasan Perkawinan Ditinjau dari Kebersyukuran dan Pemaafan pada Pasangan Bekerja
}

\author{
Icha Herawati, Syarifah Farradinna \\ syarifah.farradinna@psy.uir.ac.id
}

Fakultas Psikologi, Universitas Islam Riau, Pekanbaru, Indonesia

\begin{abstract}
This study aims to identify marital satisfaction among married, working individuals in relation with the aspect of gratitude and forgiveness. This study was conducted by using survey methods through questionnaires. The samples of this study were 226 married, working individuals (140 males and 86 females) and were working for Islamic University of Riau (UIR), Indonesia. The instruments for this study were the adaptation of The Gratitude Questionnaire-Six Item Form (GQ-6) for the aspect of gratitude, Marital Forgiveness Scale (dispositional) for the aspect of forgiveness and ENRICH Marital Satisfaction Scale for the aspect of marital satisfaction. The result showed a significant correlation between gratitude, forgiveness, and maritl satisfaction. The statistical regression also found that forgiveness is the key contributor of marital satisfaction for married, working individual. In general, this study suggest that gratitude and forgiveness is an important aspect that contributes to marital satisfaction of married, working individuals.
\end{abstract}

\begin{abstract}
Penelitian ini bertujuan untuk mengetahui kepuasan perkawinan pada pekerja yang telah menikah yang dilihat dari aspek kebersyukuran dan pemaafan. Penelitian ini dilakukan dengan metode survey menggunakan kuesioner. Sampel penelitian terdiri dari 226 orang yang telah menikah dan sedang bekerja (pria $=140$, wanita=86) di Universitas Islam Riau (UIR), Indonesia. Instrumen kajian adalah adaptasi dari The Gratitude Questionnaire-Six Item Form (GQ-6) untuk aspek kebersyukuran, Marital Forgiveness Scale (Dispositional) untuk aspek pemaafan, dan ENRICH Marital Satisfaction Scale untuk aspek kepuasan perkawinan. Hasil penelitian menunjukkan bahwa terdapat hubungan yang signifikan antara kebersyukuran, pemaafan, dan kepuasan perkawinan. Hasil uji regresi menunjukkan bahwa pengampunan merupakan aspek kunci pada pasangan suami istri yang memperoleh kepuasan perkawinan. Secara keseluruhan, penelitian ini menunjukkan bahwa kebersyukuran dan pemaafan merupakan aspek penting untuk memberi kontribusi pada kepuasan perkawinan terhadap individu bekerja yang telah menikah.
\end{abstract}

Kata kunci: kebersyukuran; pemaafan; kepuasan pernikahan

Received: June 16, 2017 Accepted: November 27, 2017

How to cite: Herawati, I., \& Farradinna, S. (2017).

Kepuasan perkawinan ditinjau dari kebersyukuran dan pemaafan pada pasangan bekerja. MEDIAPSI, 3(2), 1021. doi:http://dx.doi.org/10.21776/ub.mps.2017.003.02.2

\section{Pendahuluan}

Agama Islam telah mengajarkan bahwa perkawinan adalah ibadah dan melengkapi kesempurnaan iman. Perkawinan memberikan manfaat terhadap kesehatan fisik dan psikologis, meningkatkan pendapatan, perkembangan anak-anak, kepuasan hubungan seksual dan memanjangkan usia kehidupan seseorang (Stutzer \& Frey, 2006). Individu, terutama pasangan menikah, penting untuk meningkatkan kebahagiaan dan kesejahteraannya dalam membina rumah tangga. Salah satu caranya adalah dengan bersyukur terhadap apa yang dilakukannya (Algoe, Gable, \& Maisel, 2010). Menurut Watkins, Woodward, Stone, dan Kolts (2003) kebersyukuran mempunyai hubungan dengan berbagai aspek dan komponen terhadap kebahagiaan. Individu yang mempunyai pola pikir untuk terus menerus bersyukur adalah 
individu yang bahagia. Kebersyukuran dapat meningkatkan individu untuk menikmati manfaat yang mereka peroleh dari suatu hubungan yang positif sehingga mencapai manfaat emosi yang positif (Emmons \& McCullough, 2002). Salah satu emosi positif yang dapat dicapai adalah memberikan pemaafan kepada pasangan, anak, dan keadaan yang dijalankan. Pemaafan dapat membantu individu untuk mengurangi kesan negatif ke arah kesejahteraan dan hubungan yang berawal dari hubungan tersebut. Kajian oleh Bono dan McCullough (2006) menemukan manfaat dari kebersyukuran dan pemaafan penting bagi individu untuk meningkatkan kesejahteraan dan emosi yang positif.

Berbagai studi menyebutkan bahwa pasangan bekerja lebih banyak berhadapan dengan konflik. Permasalahan yang muncul diprediksi berasal dari ketidakseimbangan peran yang dijalani oleh suami maupun istri (Gradianti \& Suprapti, 2014; Pujiastuti \& Retnowati, 2004; Rapoport \& Rapoport, 1976). Penelitian terdahulu juga menemukan apabila pasangan tidak menunjukkan kebahagiaan rumah tangga atau lebih mementingkan kerja, maka hal dapat merusak kepuasan perkawinan itu sendiri. Peran yang tidak seimbang antara suami dan istri dalam rumah tangga dapat menyebabkan ketidakstabilan perkawinan (Lubis, Namora, \& Syahfitriani, 2007) sehingga berakhir kepada perceraian. Statistik yang dikeluarkan oleh Pengadilan Agama Kelas 1A Pekanbaru Riau pada tahun 2015, kasus perceraian yang terjadi sebanyak 1362 dan yang telah tercatat pada bulan Oktober 2016 telah mencapai 811 kasus perceraian dan diprediksi akan meningkat hingga akhir tahun 2016.

Pengadilan Agama Kelas 1A yang menangani permasalahan perkawinan mendapati bahwa perceraian yang terjadi tiap tahunnya pada usia perkawinan yang masih muda yaitu di bawah sepuluh tahun. Kecenderungan tuntutan perceraian kebanyakan diajukan oleh pihak istri terhadap suami, yakni mencapai lebih dari 50\% kasus. Kasus perceraian yang terjadi di Pekanbaru didominasi oleh kasus perceraian pasangan yang bekerja.

Melihat permasalahan ini, perlu adanya tindakan untuk melihat dan mengkaji bagaimana mempertahankan rumah tangga individu bekerja yang telah menikah untuk menghindari masalah perceraian yang datang di kemudian hari. Konflik rumah tangga tidak dapat dielakkan ataupun dihilangkan. Oleh sebab itu, perlu adanya kesadaran pada individu bekerja yang telah menikah untuk mencari penyelesaian dengan memahami dan memaafkan kesalahan pasangan bagi mempertahankan pernikahannya. Apabila kepuasan perkawinan mengalami penurunan dalam kalangan individu menikah, ini akan memberi pengaruh kepada tahap kelekatan pasangan suami istri (Ng, Loy, MohdZain, \& Cheong, 2013).

Menurut Safarzadeh, Esfahaniasl, dan Bayat (2011), kepuasan perkawinan akan memberi pengaruh kepada penilaian kebahagiaan individu dan merupakan kunci utama dalam suatu perkawinan. Beberapa penelitian yang telah dijalankan menemukan bahwa pemaafan ialah gejala yang penting dalam perkawinan yang menjelaskan bagaimana pasangan mengatasi konflik antar pasangan (Mathias, Amberg, \& Zimprich, 2007), mengatasi konflik di masa depan (Fincham, Beach, \& Davila, 2004), berpengaruh terhadap kesehatan batin (Seif \& Bahari, 2003) serta efektif dalam pikiran, perasaan, dan meningkatkan hubungan (Kachadourian, 
Fincham, \& Davila, 2005).

Berdasarkan penelitian yang dilakukan Algoe, dkk. (2010), rasa syukur mampu meningkatkan kelekatan dan kepuasan pasangan dalam menjalani kehidupan. Mengungkapkan rasa syukur juga mampu meningkatkan perilaku memberikan bantuan, mendorong lahirnya tingkah laku prososial (Emmon \& McCullough, 2003), meningkatkan kebahagiaan dan kepuasan hidup (Toepfer \& Walker, 2009), serta mewujudkan perilaku positif (Wood, Josept, \& Maltby, 2008).

Penelitian terdahulu telah banyak mengumpulkan dan mencari pembahasan yang paling tepat dalam menentukan sifat, penyebab, dan akibat rasa syukur secara keilmuan, sehingga beberapa pendapat menyimpulkan definisi rasa syukur sebagai komponen penting untuk kesehatan, pelengkap kekurangan, dan kesejahteraan. Kashdan, Mishra, Breen, dan Froh (2006) mengatakan kebersyukuran merupakan sebuah apresiasi dan rasa berterima kasih terhadap manfaat yang diterima, tidak menghitung ada atau tidaknya manfaat tersebut, manusia atau sumber spiritual ataupun keberuntungan yang dapat mendorong individu untuk menjalankan kehidupan yang lebih memuaskan dan bermakna. Sementara Emmons (2007) mengatakan kebersyukuran sebagai pengakuan yang positif apabila menerima sesuatu yang bermanfaat atau nilai tambah yang berkaitan dengan penilaian bahwa terdapat pihak-pihak lain yang bertanggung jawab terhadap nilai tambah diri.

Kajian oleh Froh, Yurkewicz, dan Kashdan (2009) menemukan bahwa kebersyukuran mengarahkan seseorang untuk memandang dirinya lebih positif. Kajian kuantitatif ini dilakukan kepada 154 orang rensponden yang diminta mengisi lembaran kebersyukuran, kepuasan hidup, optimisme, dukungan sosial, dan tingkah laku prososial. Di lain pihak Algoe, dkk. (2010) juga melakukan survey kepada 64 pasangan atau 134 orang yang menjalankan hubungan romantis yang memiliki periode perkawinan setidaknya lebih dari tiga bulan di daerah Barat Amerika Serikat yang merupakan pelajar dan pekerja di universitas.

Secara konseptual, pemaafaan dapat didefinisikan sebagai satu paket motivasi dalam suatu tindakan untuk membangun hubungan yang lebih baik dari arah negatif ke arah yang lebih positif terhadap kesalahan atas kesadaran diri sendiri dan mempunyai harapan untuk selalu menciptakan kedamaian. Penelitian yang sejalan seperti Nancy, Wismanto, dan Hastuti (2014) menemukan bahwa untuk mengetahui hubungan nilai dalam perkawinan dan pemaafan dengan keharmonisan keluarga. Penelitian tersebut menggunakan metode penelitian kuantitatif dengan sampel pasangan suami istri yang tinggal di Maumere, Indonesia yang berjumlah 100 pasangan.

Pasangan yang dapat mengatasi konflik keluarga maka akan terhindar dari masalah yang dapat mengganggu fokusnya pada pekerjaan. Kajian deskriptif ini didukung oleh Askari (2016) yang melakukan kajian terhadap 80 pasangan penduduk di Tehran, Iran menggunakan Marital Forgiveness Scale (MOFS) oleh Paleari, Regalia, dan Fincham (2009) dan Enrich Couple Measure. Hasil penelitian tersebut menemukan bahwa ada hubungan yang signifikan antara pemaafan dengan kepuasan perkawinan. Penelitian ini juga mendapatkan bahwa memaafkan dapat merubah perasaan tersinggung dan pikiran negatif terhadap pasangan. Alat ukur yang digunakan bertujuan untuk mengukur 
keharmonisan keluarga. Alat ukur ini berupa penilaian individu dalam perkawinan dan disesuaikan berdasarkan Forgiveness Scale dari Rye, dkk. (2001) untuk mengukur pemaafan. Hasil penelitian menunjukkan bahwa terdapat hubungan positif antara nilai dalam perkawinan dan pemaafan dengan keharmonisan keluarga. Terdapat pula hubungan positif antara nilai dalam perkawinan dengan keharmonisan keluarga dan terdapat hubungan positif antara pemaafan dengan keharmonian keluarga.

Sementara itu, kepuasan perkawinan merupakan pembinaan multidimensi yang terdiri dari berbagai komponen (Sousou, 2004). Berdasarkan perspektif evolusi Buss (1989), kepuasan perkawinan dapat dilihat sebagai satu keadaan psikologi yang dikontrol oleh mekanisme dalam mengawasi kepentingan perkawinan kepada orang tertentu. Sedangkan menurut Lemme (1995), kepuasan perkawinan adalah perbaikan suami dan istri terhadap hubungan pernikahan yang cenderung berubah sepanjang perjalanan perkawinan. Kepuasan perkawinan dapat merujuk pada bagaimana pasangan suami istri memperbaiki hubungan perkawinan mereka apakah memuaskan atau tidak (Hendrick \& Hendrick, 1992).

Sebuah penelitian yang telah dilakukan menyebutkan bahwa wanita yang berusia di atas 25 tahun yang telah menikah berpendapat bahawa faktor-faktor yang menyumbang terhadap kepuasan perkawinan di antaranya cinta, pengertian, rasa hormat, komitmen, saling berbagi, kepedulian, pendidikan, dan status ekonomi (Fatima \& Ajmal, 2012). Sejalan dengan itu, peneliti seperti Wendorf, Lucas, Imamoglu, dan Weisfeld (2010) melakukan penelitian mengenai pengaruh jumlah anak terhadap cinta istri dalam kalangan pasangan suami istri di Amerika Serikat, Inggris, dan Turki. Penelitian ini melaporkan bahwa jumlah anak berpengaruh negatif secara signifikan terhadap kepuasan perkawinan bagi pasangan suami istri di Amerika Serikat, Inggris, dan Turki. Hasil analisis studi ini menunjukkan bahwa dengan bertambahnya jumlah anak dalam sebuah keluarga maka akan menambah beban keluarga dari segi pendapatan keluarga.

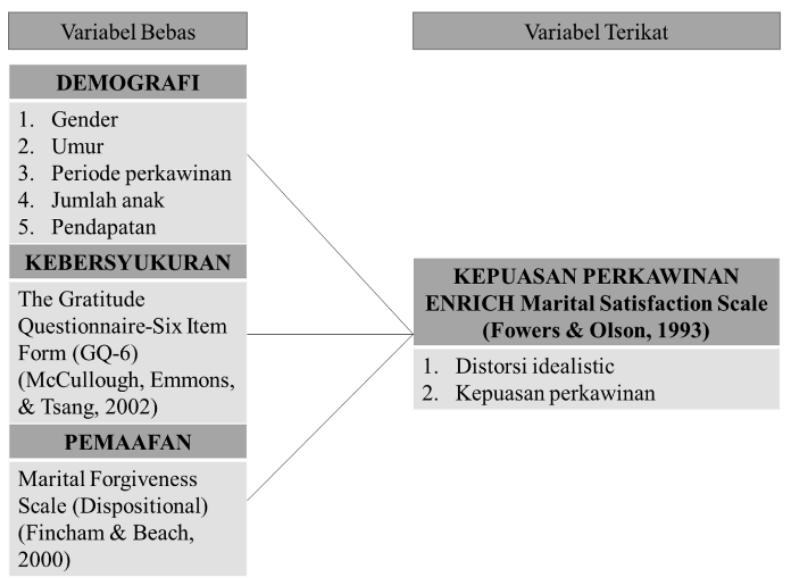

Gambar 1. Kerangka berpikir kebersyukuran dan pemaafan terhadap kepuasan perkawinan.

Berdasarkan permasalahan kajian yang telah dibahas sebelumnya, peneliti ingin melihat sejauh mana tahap kebersyukuran, pemaafan, dan kepuasan perkawinan pada kalangan individu bekerja yang menikah dan sejauh mana hubungan antara faktor psikologi (kebersyukuran dan pemaafan) dengan kepuasan perkawinan pada kalangan individu bekerja yang menikah. Mengikuti alur seterusnya, tujuan penelitian ini secara khusus adalah untuk mengukur kebersyukuran, pemaafan, dan kepuasan perkawinan pekerja dan mengidentifikasi faktor-faktor demografi yang berkontribusi terhadap kepuasan perkawinan. Selain itu, penelitian ini juga bertujuan untuk melihat kaitan antara kebersyukuran terhadap kepuasan perkawinan. Kerangka berpikir sebagaimana 
ditunjukkan pada Gambar 1 menggambarkan hubungan di antara variabel bebas dan terikat dalam satu kerangka. Berdasarkan hasil dari ulasan pustaka yang telah dilakukan sebelumnya, kerangka berpikir dalam penelitian ini yaitu terdapat variabel bebas yang terdiri dari demografi, kebersyukuran, dan pemaafan. Sementara itu, variabel terikatnya adalah kepuasan perkawinan.

\section{Metode}

Desain penelitian yang dilakukan pada penelitian ini adalah one shot study (Dyer, 2006) berbentuk tinjauan dengan menggunakan kuesioner. Menurut Keele dan Kelly (2006), one shot study adalah sebuah studi yang dijalankan kepada satu kelompok individu yang dipilih untuk diperhatikan dalam jangka waktu yang terbatas. Responden yang dipilih diminta untuk menjawab satu set kuesioner yang mengandung beberapa bagian yang telah disesuaikan untuk mencapai tujuan penelitian.

Sampel penelitian ini terdiri dari 140 orang laki-laki dan 86 orang perempuan bekerja yang telah menikah di Universitas Islam Riau (UIR). Faktor utama yang menyebabkan Universitas Islam Riau (UIR) dipilih sebagai lokasi penelitian adalah karena UIR merupakan universitas swasta terbesar di Riau. Universitas Islam Riau memiliki 11 bagian yang terdiri atas sembilan fakultas dan dua direktur lembaga.

Penelitian ini telah menggunakan alat pengukuran berbentuk kuesioner. Menurut Tuckman (1978) instrumen berbentuk kuesioner merupakan salah satu cara yang paling berpengaruh untuk mendapatkan informasi dari responden. Kuesioner pada penelitian ini terdiri dari empat bagian, yaitu bagian pertama (Bagian A) yang berkaitan dengan informasi demografi responden, terdapat sepuluh butir pertanyaan yaitu jenis kelamin, umur, tahap pendidikan, pendapatan per bulan, periode perkawinan, jumlah anak, usia anak sulung, usia anak bungsu, dan pemilihan pasangan sebelum menikah.

Bagian B adalah pernyataan yang berkaitan dengan kebersyukuran. Setiap butir penyataan ini diadaptasi dari The Gratitude Questionnaire-Six Item Form (GQ-6) oleh McCullough, Emmons, dan Tsang (2002). Penyataan pada kuesioner tersebut mengandung enam butir yang dibuat berdasarkan empat aspek rasa syukur yaitu intensity (intensitas), frequency (kekerapan), span (rentang), dan density (ketumpatan).

Bagian $\mathrm{C}$ merupakan penyataan yang berkaitan dengan pemaafan pada individu yang menikah. Pernyataan yang digunakan untuk mengukur pemaafan dalam kehidupan berumah tangga ini diadaptasi dari Marital Forgiveness Scale (Dispositional) yang telah disusun oleh Fincham dan Beach (2000). Penyataan pada kuesioner ini mengandung tiga domain yang terkumpul menjadi enam butir.

Terakhir, Bagian D adalah penyataan tentang kepuasan perkawinan bagi individu yang menikah. Kuesioner ENRICH Marital Satisfaction Scale yang digunakan didasarkan kepada soalan yang telah disusun oleh Fowers dan Olson (1993). Pernyataan pada kuesioner ini telah diadaptasi dan mengandung 15 butir dalam dua domain, yaitu kepemilikan idealistik dan kepuasan perkawinan.

Analisis data yang digunakan dalam penelitian ini adalah analisis statistik deskriptif dan analisis inferensial. Analisis inferensial yang digunakan adalah analisis uji beda, korelasi, dan regresi terhadap faktor demografi, kebersyukuran, dan pemaafan 
terhadap kepuasan perkawinan.

\section{Hasil}

\section{Analisis deskriptif}

Aanalisis statistik deskriptif dan inferensial dilakukan pada penelitian ini berdasarkan pengumpulan data yang telah dilakukan kepada 226 orang karyawan Universitas Islam Riau yang telah menikah, tinggal bersama pasangan, menikah lebih dari satu tahun, dan bersedia menjadi partisipan dalam penelitian ini. Informasi yang telah dirangkum dalam profil demografi adalah gender, umur, tahap pendidikan, pendapatan, periode perkawinan, dan jumlah anak. Hasil analisis statistik deskriptif dapat dilihat pada Tabel 1.

Tabel 1

Gambaran Informasi Responden

\begin{tabular}{|c|c|c|}
\hline Variabel & Jumlah & Persentase \\
\hline \multicolumn{3}{|l|}{ Gender } \\
\hline Pria & 140 & 61.9 \\
\hline Wanita & 86 & 38.1 \\
\hline \multicolumn{3}{|l|}{ Umur (tahun) } \\
\hline $25-36$ & 114 & 50.4 \\
\hline $37-48$ & 71 & 31.4 \\
\hline $49-60$ & 41 & 18.1 \\
\hline \multicolumn{3}{|l|}{ Tingkat pendidikan } \\
\hline SMP & 6 & 2.7 \\
\hline SMA & 62 & 27.4 \\
\hline Starta $1(\mathrm{~S} 1)$ & 92 & 40.7 \\
\hline Strata $2(\mathrm{~S} 2)$ & 62 & 27.4 \\
\hline Strata 3 (S3) & 4 & 1.8 \\
\hline \multicolumn{3}{|l|}{ Pendapatan } \\
\hline Rp. 1 juta - Rp. 5 juta & 160 & 70.8 \\
\hline Rp. 5.1 juta - Rp. 10 juta & 58 & 25.7 \\
\hline Rp. 10 juta ke atas & 8 & 3.5 \\
\hline \multicolumn{3}{|l|}{ Periode perkawinan } \\
\hline $1-8$ tahun & 106 & 46.9 \\
\hline 9-17 tahun & 52 & 23 \\
\hline 18-26 tahun & 50 & 22.1 \\
\hline 27-35 tahun & 18 & 8 \\
\hline \multicolumn{3}{|l|}{ Jumlah anak } \\
\hline $0-2$ orang & 166 & 73.4 \\
\hline 3-5 orang & 56 & 24.8 \\
\hline $6-8$ orang & 4 & 1.8 \\
\hline
\end{tabular}

Selain analisis deskriptif terhadap demografi, analisis deskriptif selanjutnya juga dilakukan terhadap variabel kebersyukuran, pemaafan, dan kepuasan perkawinan yang dikategorisasi ke dalam tiga tingkatan yaitu rendah, sedang, dan tinggi. Selain itu, dilaporkan pula nilai rata-rata dan standar deviasi setiap variabel yang ada. Selengkapnya dapat dilihat pada Tabel 2.

Tabel 2

Deskriptif Tahapan Respon Kebersyukuran, Pemaafan, dan Kepuasan Perkawinan

\begin{tabular}{lccccc}
\hline \multirow{2}{*}{ Variabel } & \multicolumn{4}{c}{ Tingkatan respon } & \multirow{2}{*}{ Rerata SD } \\
\cline { 2 - 5 } & Rendah & Sedang & Tinggi & & \\
\hline Kebersyukuran & $\begin{array}{c}41 \\
(18 \%)\end{array}$ & $\begin{array}{c}175 \\
(77.43 \%)\end{array}$ & $\begin{array}{c}10 \\
(4.42 \%)\end{array}$ & 36.57 & 4.55 \\
\hline Pemaafan & 32 & 164 & 30 & 27.7 & 4.9 \\
\hline Kepuasan & $(14.15 \%)$ & $(72.57 \%)$ & $(13.28 \%)$ & & \\
Perkawinan & $(13.27 \%)$ & $\begin{array}{c}152 \\
(67.26 \%)\end{array}$ & $\begin{array}{c}44 \\
(19.47 \%)\end{array}$ & 59.58 & 7.2 \\
\hline
\end{tabular}

Berdasarkan informasi pada Tabel 2, tingkat kebersyukuran responden dalam penelitian ini mayoritas berada pada tingkat sedang yaitu sebanyak 77.43 persen. Sementara itu, pemaafan umumnya direspon pada tingkat sedang sebanyak 72.57 persen. Walaupun tampak tingkat kepuasan perkawinan cenderung direspon pada tingkat sedang sebanyak 67.26 persen, namun tingkatan respon tinggi pada kepuasan perkawinan di kalangan karyawan menunjukkan respon paling banyak yaitu sebesar 19.47 persen.

\section{Analisis inferensial}

Analisis inferensial dalam penelitian ini terdiri dari analisis uji beda, korelasi, dan regresi kepada faktor demografi, kebersyukuran, dan pemaafan terhadap kepuasan perkawinan. Keseluruhan analisis statistik yang digunakan adalah untuk menjawab hipotesis penelitian dan menjawab 
rumusan masalah penelitian.

Tabel 3 menggambarkan bahwa uji perbedaan kepuasan perkawinan antara pria dan wanita menunjukkan $t=2.608 ; p \leq 0.01$. Hal ini menunjukkan bahwa terdapat perbedaan signifikan kepuasan perkawinan antara pria dan wanita. Hasil analisis ini juga menunjukkan bahwa respon kepuasan perkawinan pada pria lebih tinggi $(M=51.73)$ jika dibandingkan dengan respon kepuasan perkawinan pada wanita $(M=50.19)$. Oleh karena itu, dapat disimpulkan bahwa hipotesis penelitian ini diterima.

Tabel 3

Analisis Pengukuran Uji Beda Kepuasan Perkawinan Berdasarkan Gender

\begin{tabular}{lccccccc}
\hline \multicolumn{1}{c}{ Variabel } & Gender & N & Rerata & SD & Sig & t & df \\
\hline Kepuasan & Pria & 140 & 51.73 & 4.189 & & & \\
Perkawinan & Wanita & 86 & 50.19 & 4.394 & .010 & 2.608 & 224 \\
& & & & & & \\
\hline
\end{tabular}

Analisis varian juga dilakukan terhadap aktor demografi umur. Analisis ini dilakukan untuk membuktikan perbedaan kepuasan perkawinan berdasarkan faktor umur. Hasil analisis statistik selengkapnya dapat dilihat dalam Tabel 4.

Tabel 4

Analisis Uji Beda (Analisis Varian) Kepuasan Perkawinan Berdasarkan Umur

\begin{tabular}{lccccc}
\hline \multicolumn{1}{c}{ Variabel } & $\begin{array}{c}\text { Sum of } \\
\text { Squares }\end{array}$ & df & $\begin{array}{c}\text { Mean } \\
\text { Square }\end{array}$ & F & Sig \\
\hline $\begin{array}{l}\text { Antar } \\
\text { Kelompok }\end{array}$ & 1077.710 & 30 & 35.924 & & \\
$\begin{array}{l}\text { Dalam } \\
\text { Kelompok }\end{array}$ & 3129.759 & 195 & 16.050 & 2.238 & .001 \\
Total & 4207.469 & 225 & & & \\
\hline
\end{tabular}

Tabel 4 di atas menunjukkan bahwa $\mathrm{F}_{\text {hitung }}=2.238 ; \quad p \leq 0.01, \quad$ sehingga hipotesis penelitian ini dinyatakan diterima. Dengan kata lain, terdapat perbedaan yang signifikan dalam kepuasan perkawinan berdasarkan umur. Pengambilan keputusan perbedaan kepuasan perkawinan berdasarkan umur merujuk kepada nilai $F_{\text {tabel }}$ di mana $F$ berdasarkan nilai $\mathrm{df}_{30.195}=1.52$. Apabila $\mathrm{F}_{\text {tabel }}<\mathrm{F}_{\text {hitung, maka dapat dinyatakan bahwa }}$ terdapat perbedaan kepuasan perkawinan berdasarkan umur. Hasil analisis penelitian ini menunjukkan $1.52<2.238$ sehingga hipotesis penelitian ini dinyatakan diterima. Dengan kata lain, terdapat perbedaan signifikan kepuasan perkawinan berdasarkan umur.

Analisis perbedaan selanjutnya adalah perbedaan kepuasan perkawinan berdasarkan faktor demografi periode perkawinan. Analisis statistik untuk menguji hipotesis ini dilakukan melalui analisis varian dengan merujuk kepada nilai $\mathrm{F}$ dengan taraf signifikansi 5\%. Tabel 5 menunjukkan bahwa $F_{\text {hitung }}=2.738 ; \quad p \leq 0.01 \quad$ sehingga hipotesis penelitian ini dinyatakan diterima, yaitu terdapat perbedaan signifikan kepuasan perkawinan berdasarkan periode perkawinan. Pengambilan keputusan perbedaan kepuasan perkawinan berdasarkan periode perkawinan merujuk kepada nilai $F_{\text {tabel }}$ di mana berdasarkan nilai $\mathrm{df}_{30.195}=1.52$. Apabila $\mathrm{F}_{\text {tabel }}<$ $F_{\text {hitung, maka dapat dinyatakannterdapat }}$ perbedaan kepuasan perkawinan berdasarkan periode perkawinan. Hasil analisis penelitian ini menunjukkan $1.52<2.738$ sehingga hipotesis penelitian ini dinyatakan diterima. Hal ini bermakna bahwa terdapat perbedaan signifikan kepuasan perkawinan berdasarkan periode perkawinan.

Tabel 5

Analisis Uji Beda (Analisis Varian) Kepuasan Perkawinan Berdasarkan Periode Perkawinan

\begin{tabular}{cccccc}
\hline Variabel & $\begin{array}{c}\text { Sum of } \\
\text { Squares }\end{array}$ & df & $\begin{array}{c}\text { Mean } \\
\text { Square }\end{array}$ & F & Sig \\
\hline Antar Kelompok & 1246.993 & 30 & 41.566 & & \\
Dalam Kelompok & 2960.476 & 195 & 15.182 & &
\end{tabular}


Total

$4207.469 \quad 225$

Analisis hubungan di antara keseluruhan variabel yang diteliti dilakukan dengan analisis korelasional dari Pearson. Hasil analisis selengkapnya dapat dilihat pada Tabel 6, yang secara garis besar menunjukkan bahwa kebersyukuran berkorelasi sangat signifikan $(p<0.01)$ dengan pemaafan, kepuasan perkawinan, gender, umur, dan periode perkawinan. Sementara itu, pemaafaan berkorelasi dengan kepuasan perkawinan secara signifikan dengan $p<0.05$.

Selain analisis perbedaan dan korelasi, peneliti juga merasa perlu untuk melakukan analisis lanjutan seperti analisis regresi yang bertujuan untuk melihat seberapa besar interaksi antara kebersyukuran dan pemaafan terhadap kepuasan perkawinan. Analisis regresi dalam penelitian ini menunjukkan bahwa faktor kebersyukuran dan pemaafan berpengaruh terhadap kepuasan perkawinan. Kesimpulan model menunjukkan bahwa

Tabel 6

Analisis Korelasional Variabel Bebas dan Terikat kebersyukuran dan pemaafaan berpengaruh terhadap kepuasan perkawinan dengan $r=0.268$ dan memberikan kontribusi terhadap kepuasan perkawinan sebesar 7.2 persen. Tabel ANOVA menunjukkan bahwa terdapat hubungan yang signifikan antara variabel prediktor kebersyukuran dan pemaafan dengan kepuasan perkawinan $\quad(F(2.223)=8.614$, $p<0.01)$. Hasil kesimpulan selengkapnya dapat dilihat pada Tabel 7.

Berdasarkan hasil analisis yang telah dipaparkan, diketahui bahwa variabel bebas kebersyukuran dan pemaafan adalah prediktor yang penting untuk menentukan kepuasan perkawinan. Oleh karena itu, dapat dinyatakan bahwa hipotesis dalam penelitian ini adalah diterima.

\section{Diskusi}

Berdasarkan analisis yang telah dilakukan, diketahui bahwa kebanyakan karyawan merespon kebersyukuran dalam

\begin{tabular}{|c|c|c|c|c|c|c|c|}
\hline & & $\begin{array}{c}\text { Total } \\
\text { Syukur }\end{array}$ & Total Maaf & $\begin{array}{c}\text { Total } \\
\text { Kepuasan } \\
\text { Perkawinan } \\
\end{array}$ & Gender & Umur & $\begin{array}{c}\text { Periode } \\
\text { Perkawinan }\end{array}$ \\
\hline \multirow{3}{*}{ Total Syukur } & Pearson Correlation & 1 & & & & & \\
\hline & Sig. (2-tailed) & & & & & & \\
\hline & $\mathrm{N}$ & 226 & & & & & \\
\hline \multirow{3}{*}{ Total Maaf } & Pearson Correlation & $.327^{* *}$ & 1 & & & & \\
\hline & Sig. (2-tailed) & .000 & & & & & \\
\hline & $\mathrm{N}$ & 226 & 226 & & & & \\
\hline \multirow{4}{*}{$\begin{array}{l}\text { Total Kepuasan } \\
\text { Perkawinan }\end{array}$} & Pearson Correlation & $.256^{* *}$ & $.158^{*}$ & 1 & & & \\
\hline & Sig. (2-tailed) & .000 & .017 & & & & \\
\hline & $\mathrm{N}$ & 226 & 226 & 226 & & & \\
\hline & Pearson Correlation & -.067 & .032 & $-.174^{* *}$ & 1 & & \\
\hline \multirow[t]{2}{*}{ Gender } & Sig. (2-tailed) & .315 & .629 & .009 & & & \\
\hline & $\mathrm{N}$ & 226 & 226 & 226 & 226 & & \\
\hline \multirow{3}{*}{ Umur } & Pearson Correlation & $-.141^{*}$ & -.032 & .083 & $-.234^{* *}$ & 1 & \\
\hline & Sig. (2-tailed) & .034 & .637 & .216 & .000 & & \\
\hline & $\mathrm{N}$ & 226 & 226 & 226 & 226 & 226 & \\
\hline \multirow{3}{*}{$\begin{array}{l}\text { Periode } \\
\text { Perkawinan }\end{array}$} & Pearson Correlation & $-.162^{*}$ & -.059 & .063 & -.077 & $.884^{* *}$ & 1 \\
\hline & Sig. (2-tailed) & .015 & .378 & .349 & .249 & .000 & \\
\hline & $\mathrm{N}$ & 226 & 226 & 226 & 226 & 226 & 226 \\
\hline
\end{tabular}

** Correlation is significant at the 0.01 level (2-tailed).

*Correlation is significant at the 0.05 level (2-tailed). 
tahap sedang. Hal ini berarti bahwa kebersyukuran dianggap penting dalam memberikan pengaruh terhadap kehidupan individu secara positif (Emmons \& McCullough, 2003). Walaupun dihadapkan kepada rutinitas pekerjaan, kepentingan pemenuhan kepuasan dalam lingkungan keluarga menjadi salah satu pendukung dalam aktivitas bekerja. Pekerjaan menjadi salah satu faktor pendukung secara tidak langsung dalam meningkatkan pendapatan ekonomi keluarga.

Tabel 7

Ringkasan Model Regresi Pengaruh Kebersyukuran Dan Pemaafaan Terhadap Kepuasan Perkawinan

\begin{tabular}{ccccc}
\hline Model & $\mathbf{R}$ & $\mathbf{R}^{\mathbf{2}}$ & $\mathbf{R}^{\mathbf{2}}$ disesuaikan & $\mathbf{F}$ \\
\hline 1 & 0.268 & 0.072 & 0.063 & 8.614 \\
\hline
\end{tabular}

Variabel terikat: kepuasan perkawinan

Faktor pemaafaan pula menjadi salah satu penyebab peningkatan kepuasan perkawinan. Secara keseluruhan, faktor pemaafan kebanyakan direspon dalam tahap sedang, yang ini menunjukkan bahwa memberikan maaf kepada pasangan atau kepada anggota keluarga adalah penting dilakukan ketika menghadapi berbagai masalah. Pemaafan menjadi salah satu jalan terbaik dalam menyelesaikan berbagai konflik perkawinan. Hasil penelitian ini juga sejalan dengan penelitian Kumala dan Trihadayani (2015) yang menyebutkan bahwa memaafkan mempengaruhi kesehatan mental dan merupakan cara yang alamiah untuk meningkatkan dukungan sosial dan menjaga kualitas hubungan perkawinan.

Hasil analisis yang paling baik ditunjukkan dalam respon tinggi terhadap kepuasan perkawinan. Hal ini membuktikan bahwa karyawan memiliki kesadaran terhadap pentingnya menjaga kepuasan perkawinan dalam rumah tangga, walaupun mereka juga memiliki tanggung jawab lainnya seperti bekerja. Hasil penelitian ini sejalan pula dengan Hakins dalam Kashani dan Shahram (2011) yang menjelaskan bahwa kepuasan perkawinan didefinisikan sebagai kepuasan emosi bersama dan membagikan pengalaman dengan pasangan.

Hasil analisis pada penelitian ini juga membuktikan bahwa karyawan pria lebih menunjukkan kepuasan perkawinan yang lebih baik. Hasil ini membuktikan bahwa ayah yang bekerja cenderung menunjukkan konflik kerjakeluarga yang lebih sedikit berbanding dengan ibu yang bekerja. Sejalan dengan penelitian lainnya, Unger dan Crawford (1992) menjelaskan bahwa di Amerika Serikat para pria yang telah menikah menunjukkan kepuasan perkawinan yang lebih baik daripada wanita bekerja yang telah menikah. Keterkaitan antara kebersyukuran dengan kepuasan perkawinan dalam penelitian ini telah terbukti berhubungan secara positif dan signifikan, yang bermakna bahwa pandangan positif yang ditunjukkan melalui rasa syukur meningkatkan keselarasan dalam hubungan suami istri.

Penelitian terdahulu menyebutkan bahwa rasa syukur dapat meningkatkan kebahagiaan dan keintiman yang menghasilkan kepuasan perkawinan yang lebih baik (Gordon, Arnett, \& Smith, 2011). Apabila kebersyukuran diimbangi dengan pemaafan, hal tersebut selanjutnya akan menghasilkan energi positif yang lebih baik dalam mengurangi kesulitan dalam menghadapi masalah dengan pekerjaan. Individu yang pemaaf dilaporkan lebih menunjukkan hubungan interpersonal yang lebih baik dalam kebahagiaan dan kepuasan hubungan suami istri (Karremans, van Lange, Quwerkerk, \& Kluwer, 2003).

Serangkaian hasil analisis yang telah 
dilakukan terhadap kebersyukuran dan pemaafan serta kepuasan perkawinan menunjukkan isu tersebut merupakan isu yang penting dalam kehidupan masyarakat. Hasil penelitian ini tidak hanya memberikan manfaat secara teoritis, namun juga praktis. Secara praktis, penelitian ini dapat memberikan manfaat yang bertumpu kepada keterkaitan individu secara langsung dan tidak langsung dalam mewujudkan kehidupan berumah tangga yang lebih baik. Bahkan, penelitian ini bisa menjadi acuan dalam memberikan pandangan kepada pihak-pihak yang berkenaan terhadap program pengembangan konseling perkawinan.

\section{Daftar Pustaka}

Algoe, S. B., Gable, S. L., \& Maisel, N. C. (2010). It's the little things: everyday gratitude as a booster shot for romantic relationship. Journal of the Association for Relationship Research, 17, 217-233.

Askari, Z. (2016). Forgiveness and its relationship with marital satisfaction: a sectional study. The International Journal of Indian Psychology, 3(10), 2349-3429.

Bono, G., \& McCullough, M. E. (2006). Positive responses to benefit and harm: bringing forgiveness and gratitude into cognitive psychotherapy. Journal of Cognitive Psychotherapy: An International Quarterly, 20(2), 1-10.

Buss, D. M. (1989). Conflict between the sexes: strategic interference and the evocation of anger and upset. Journal of Personality and Social Psychology, 56, 735-747.

Dyer, C. (2006). Beginning Research in
Psychology. Oxford: Blackwell.

Emmons, R. A. (2007). Thanks! How the New Science of Gratitude Can Make You Happier. New York: Houghton-Mifflin.

Emmons, R. A., \& McCullough, M. E. (2002). The grateful disposition: a conceptual andempirical topography. Journal of Personality and Social Psychology, 82(1), 112-127.

Emmons, R. A \& McCullough, M. E. (2003). Counting blessings versus burdens: an experimental investigation of gratitude and subjective well-being in daily life. Journal of Personality and Social Psychology, 84(2), 377-389.

Fatima, M. \& Ajmal., M. A. (2012). Happy marriage: a qualitative study. Pakistan Journal of Social and Clinical Psychology, 9(2), 37-42.

Fincham, F. D., \& Beach, S. R. H. (2000). The kiss of the porcupines:fFrom attributing responsibility to forgiving. Personal Relationships, 7, 1-23.

Fincham, F. D., Beach, S. R. H., \& Davila, J. (2004). Forgiveness and conflict resolution in marriage. Journal of Family Psychology, 18(1), 72-81.

Fowers, B. J., \& Olson, D. H. (1993). ENRICH Marital Satisfaction Scale: a brief research and clinical tools. Journal of Family Psychology, 7(2), 176-185.

Froh, J. J., Yurkewicz, C., \& Kashdan, T. B. (2009). Gratitude and subjective well being in early adolesences: examining gender differences. Journal of Adolesence, 32(3), 633-650.

Gradianti, T. A., \& Suprapti, V. (2014). Gaya penyelesaian konflik perkawinan pada pasangan dual-earner. Journal Psikologi 
Pendidikan dan Perkembangan, 3(3), 199-206.

Gordon, C. L., Arnette, R. A. M., \& Smith, W. E. (2011). Have you thanked your spouse today?: felt and expressed gratitude among married couples. Personality and Individual Differences, 50, 339-343.

Hendrick, S. \& Hendrick, C. (1992). Liking, Loving and Relating. Monterey, CA: Brooks/Cole Publishing Company.

Kachadourian, L. K., Fincham, F., \& Davila, J. (2005). Attitudinal ambivalence, rumination, and forgiveness of partner transgressions in marriage. Personality and Social Psychology Bulletin, 31(3), 334-342.

Karremans, J. C., van Lange P. A. M., Quwerkerk, J. W., \& Kluwer, E. S. (2003). When forgiving enchances psychological well-being: the role of interpersonal commitment. Journal of Personality and Social Psychology, 84(5), 1011-1026.

Kashdan, T. B., Mishra, A., Breen, W. E., \& Froh, J. J. (2009). Gender differences in gratitude: examining appraisals, narrative, the willingness to express emotion and changes in psychological needs. Journal of Personality, 3, 77-89.

Kashani, F. \& Shahram, V. (2011). The effect of sexual skills training on marital satisfaction. Procedia, 30, 2581-2585.

Keele, L., \& Kelly, N. J. (2006). Dynamic models for dynamic theories: the ins and outs of lagged dependent variables. Political Analysis, 14(2), 186-205.

Kumala, A., \& Trihandayani, D. (2015). Peran memaafkan dan sabar dalam menciptakan kepuasan perkawinan. Jurnal Ilmiah Penelitian Psikologi, 1(1), $39-44$.

Lemme, B. H. (1995). Development In Adulthood. Boston, MA: Allyn \& Bacon.

Lubis, N. L., \& Syahfitriani, E. (2007). Perbedaan konflik peran ganda suami ditinjau dari motivasi kerja, kebutuhan ekonomi dan aktualisasi diri pada istri. Majalah Kedokteran, 40(1), 5-12.

Mathias, A., Amberg, I., \& Zimprich, D. (2007). The role of trait forgiveness and relationship satisfaction episodic forgiveness. Journal of Social and Clinical Psychology, 26(2), 199-217.

McCullough, M. E., Emmons, R. A., \& Tsang, J. (2002). The grateful disposition: a conceptual empirical topography. Journal of Personality and Social Psychology, 82, 112-127.

Nancy, M. N., Wismanto, Y. B., \& Hauti, L. W. (2014). Hubungan nilai dalam perkawinan dan pemaafan dengan keharmonisan keluarga. Psikodimensia, 13(1), 84-97.

Ng, K., Loy, J. T., MohdZain, Z., \& Cheong, W. (2013). Gender, race, adult attachment and marital satisfaction among Malaysians. The Family Journal, 21(2), 198-207.

Paleari, F. G., Regalia, C., \& Fincham, F. D. (2009). Measuring offence-specific forgiveness in marriage: The Marital Offence-Specific Forgiveness Scale (MOFS). Psychological Assessment, 21, 194-209.

Pujiastuti, E. \& Retnowati, S. (2004). Kepuasan pernikahan dengan depresi pada kelompok wanita menikah yang 
bekerja dan yang tidak bekerja. Humanitas Indonesian Psychological Journal, 1(2), 17-33.

Rapoport, R. \& Rapoport, R. N. (1976). Dualcareer Families Re-examined. New York: Harper and Row Publishers.

Rye, M., Loiacono, D., Folk, C., Olszewski, B. T., Heim, T. A., \& Madia, B. P. (2001). Evaluation of the psychometric properties of two forgiveness scale. Current Psychology: Developmental, Learning, Personality and Social, 2(3), 260-277.

Safarzade, S., Esfahaniasl, M., \& Bayat, M. R. (2011). The relationship between forgiveness, perfectionism and intimacy and marital satisfaction in Ahwaz Islamic Azad University married students. Middle-East Journal of Scientific Research, 9(6), 778-784.

Seif, S. \& Bahari, F. (2003). Relationship between forgiveness and mental health of couple. Persian Journal of Psychological Studies, 1(1), 9-18.

Sousou, S. D. (2004). The role of agreeableness and neuroticism in marital satisfaction: actor and partner contribution. Unpublished doctoral dissertation. State University of New York at Albany.

Stutzer, A. \& Frey, B. (2006). Does marriage make people happy or do happy people get married? Journal of SocioEconomics , 35(2), 326-347.

Toepfer, S. M., \& Walker, K. (2009). Letter of gratitude: improving well-being through expressive writing. Journal of Writing Research, 1(3), 181-198.

Tuckman, B. W. (1978). Conducting
Educational Research. San Diego, CA: Harcourt Brace College Publishers.

Unger, R., \& Crawford, M. (1992). Women and Gender: A Feminist Psychology. New York: McGraw-Hills Inc.

Watkins, P. C., Woodward, K., Stone, T., \& Kolts, R. (2003). Gratitude and happiness: development of a measure of gratitude and relationships with subjective well-being. Social Behaviour and Personality, 31(5), 431-452.

Wendorf, C. A., Lucas, T., Imamoglu, E. O., \& Weisfeld, G. F. (2011). Marital satisfaction across three cultures: does the number of children have an impact after accounting for other marital demographics? Journal of CrossCultural Psychology, 42(3), 340-354.

Wood, A. M., Joseph, S., \& Maltby, J. (2008). Gratitude uniquely predicts satisfaction with life: incremental validity above the domains and facets of the five factor model. Personality and Individual Differences, 45(1), 49-54. 